\title{
A Tale of Two Souths \\ The Faulknerian Ideologeme in Vicente Groyon's The Sky over Dimas
}

Ma. Gabriela P. Martin
Ateneo de Manila University

\section{Abstract}

This paper lays bare the re-working of the ideologemes in William Faulkner's Go Down, Moses (1942) and Absalom, Absalom! (1936) in Vicente Groyon's novel The Sky Over Dimas (2003). Ideologemes, in Fredric Jameson's The Political Unconscious: Narrative as a Socially Symbolic Act, are inherited narrative paradigms which are constitutive of a class discourse. In his postmodern work, Groyon modifies the ideologeme of the white patriarch's 'grand design' in Absalom, Absalom! and the ideologeme of renunciation in Go Down, Moses which undermine racist ideologies, to provisionalize Bacolod history, thus reifying both class discourses as gossip and speculation.

\section{Keywords}

ideologeme, dialogism, Faulkner, Negros history 


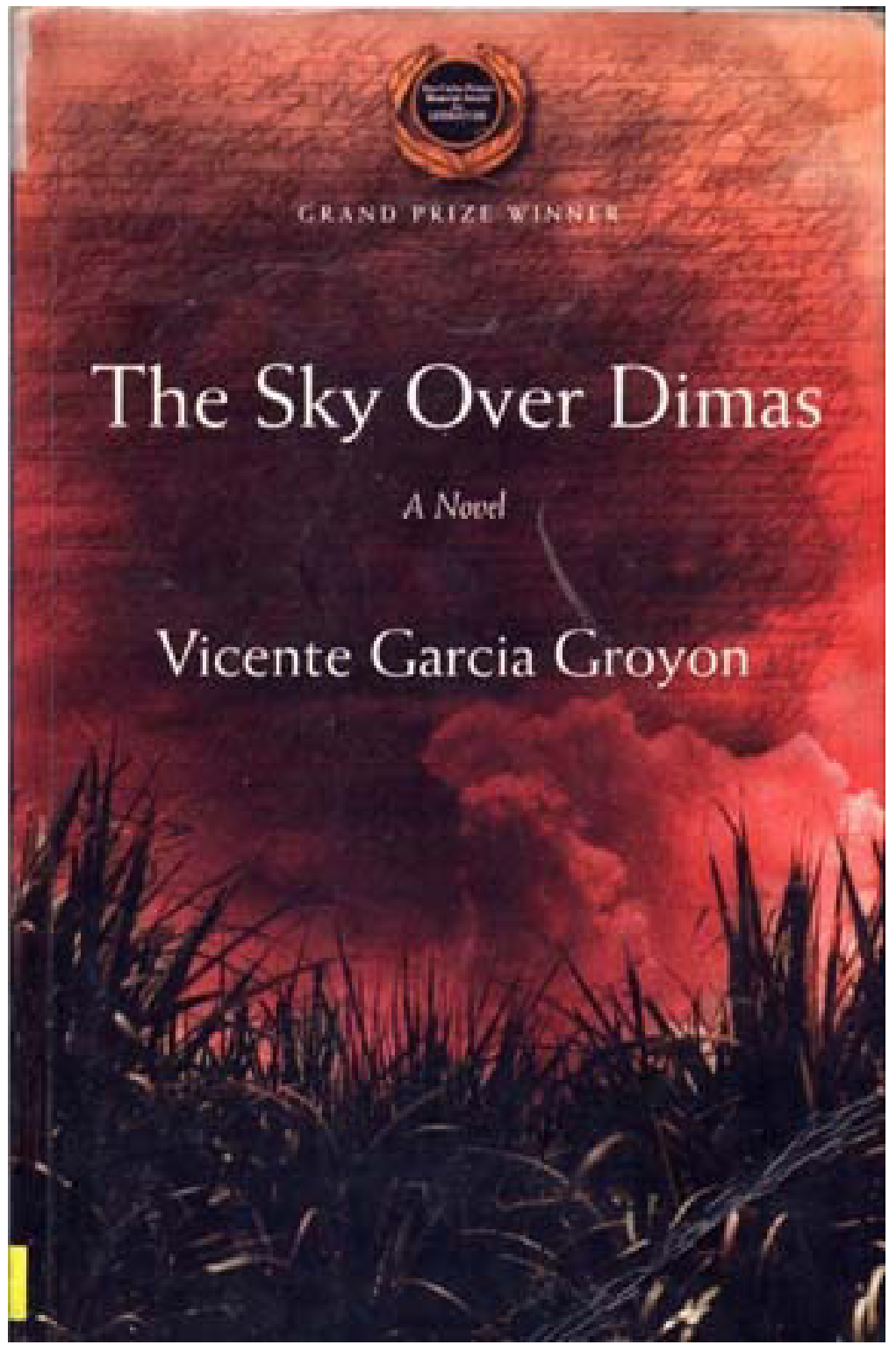

Vicente Groyon's The Sky Over Dimas (2003) 
In The Political Unconscious, Fredric Jameson foregrounds the crucial act of interpretation: "texts come before us as always-already read; we apprehend them through sedimented layers of interpretations, or-if the text is brand-new-through the sedimented reading habits and categories developed by those inherited interpretive tradition" (9). In the book, Jameson unfolds his inimitable strategy of a Marxist dialectical treatment of theory and form which enables the historicization of the text via the interpretive codes or the available theories (concepts or categories) by which we apprehend any cultural or literary work. The text may indeed be a thing in itself, an object with its own history, but we seldom read it "as is," in its naked immediacy. Instead, our ways of knowing the work always takes recourse to pre-existing interpretive modes or "strategies of containment" (e.g. humanism, ecriture blanche, readerly, expressive causality or allegory) which are themselves historically-conditioned. This emphasis on reading as a series of inherited schemes that mediate our reception of cultural products prefigures Jameson's notion of the ideologeme.

In Jameson's Marxist hermeneutic, which asserts "the priority of the political interpretation of literary texts" (17), ideologemes "are the raw material, the inherited narrative paradigms, upon which the novel as a process works and which it transforms into texts of a different order" (185). Unlike the operations of intertextuality which merely conceives of the text as a tissue of citations, the ideologeme is invested with a class content or discourse. The ideologeme, more properly, belongs to Jameson's widening of the interpretive ground or subtext to the social where the borrowed paradigm participates in "the antagonistic dialogue of class voices" (85). Implicated in this field of political and textual relations is Vicente Groyon's novel The Sky Over Dimas, whose narrative paradigms are Faulknerian, more specifically, reiterating Absalom, Absalom! and Go Down, Moses. This re-appropriation discloses the workings of Jameson's ideologeme.

The Sky over Dimas is a meta-fictional novel set in Bacolod that chronicles the troubled saga of the Torrecarion family, a hacendero clan in Bacolod whose past crimes and misdemeanors, committed in a desperate bid to keep its bloodlines free of working class progeny, are deforming its present. 
George Torrecarion and his wife Marge, if not obsessing about and denying the past, are trapped in a bubble of their own choice. George, the reluctant and inept sugar planter, "fictionalizes the present" by dissimulating madness and entertaining present day Bacolodnons with his quixotic antics; Marge indulges in hack spirituality and the convenience of a split personality. Rafael, the second of two sons, the only survivor, sends himself to college in Manila and manages to escape "the sins of the fathers." Negros history finds its way into the genealogy of the family which is half-contained by the plot and half-revealed by George Torrecarion's journals. These sources unravel one dramatic secret after another and they involve genocide, miscegenation, murder, incest, and idiocy from the first Torrecarion settler in Spanish Bacolod to the post-EDSA descendants of the clan.

That Groyon is re-visioning Faulkner in The Sky over Dimas is apparent to anyone who has read Absalom, Absalom! and Go Down, Moses. Such an appropriation of these Faulknerian paradigms suggests that the reality of the American South in Faulkner's novels resembles Bacolod history as narrativized by Groyon. Such a perceived similarity though is problematic since the concrete historical situation which enters the texture of the latter's work is different from that of the former. Groyon's novel is written out of a specific historical conjuncture that involves the longstanding conflict between the small elite group of hacenderos and the ever-growing working class in Negros. These social subtexts implicate both novels in class antagonisms such that each novel can be read as a response to an opposing class discourse. In this context, the dialogic narrative material in Absalom Absalom! and Go Down, Moses is a retort to and an undermining of the South's racist ideology that privileges the union between genealogy and power. Groyon re-appropriates this raw material although as with any borrowing of older cultural signifieds, the raw material had to accommodate a different socio-historical situation, one which did not mark its inception. Given such a re-appropriation, is The Sky over Dimas constitutive of a class ideology in the same way? Does the novel simulate the same utterance in its discourse of class? 


\section{The Dialogue of Class Struggle}

The materialist basis of Jameson's Marxism constitutes the ultimate conditions of possibility of any genre. This is especially true of the novel whose constant metamorphosis makes it an exemplary a form for revealing such a symbolic act at play, muting, subsuming, unifying, and displacing narrative paradigms which are all ideologically-charged in contradictory ways, themselves originally symbolic acts. In this manner is how Bakhtin considers all utterances to be only "relatively stable" speech genres of which the novel or any literary work is one. As speech, literary works do not really "create" original expressions or messages but instead exhibit a process of assimilation where the text is charged with "others' words" in varying degrees. These words, which the speaker or author attempts to own or shepherd into his/ her work, are derived from different epochs, social circles, or family and intersected by the various fields of human activity like law, journalism, and the sciences. In its embodiment of a world and an evaluation of it, these words which the author assimilates is re-purposed and re-accentuated in the literary work (Bakhtin 88-89).

My reading situates Groyon's novel in Jameson's second interpretive horizon where the text is restored to its mode as a class utterance or form of expression that challenges an opposing class discourse. At this level, the individual text is seen as defensive in nature, the contradiction it seeks to resolve as dialogical owing to the resolute positions and conflicts of class antagonisms (Jameson 84). This Marxist definition of class, which borrows from Bakhtin's notion of class discourse as dialogical, acknowledges that a class ideology is formed in active relation with an antagonistic one, its attitudes and beliefs dependent on and reacting to those of an opposing class that it answers back to (Jameson 84). These discourses or utterances, Bakhtin claims, are always oriented towards the other in its addressivity. An utterance is a response to previous speeches or statements and thus exists in "a link in the chain of speech communication of a particular sphere." Addressivity denotes how each discourse "refutes, affirms, supplements, and relies on the others, presupposes them to be known, and somehow takes them into account" (Bakhtin 91). On this ideological reconstruction, the text 
assumes a strategic stance in a determinate class struggle and is restored to its moment in an ongoing class dialogue, a shared code. This forwards a more critical understanding of written discourses, one that recognizes its class orientations such that the works by themselves are reinstated as contentious practices that either legitimate their own power position or undermine a dominant value system (Jameson 85-86).

An instance of such a reconstruction of the text as class discourse is Reynaldo Ileto's rereading of the pasyon as a millenarian expression of resistance that appropriates the narrative possibilities or code of religion from the hegemonic political discourse of the Spanish-colonial government. His analysis posits that the millenarian movement was able to wrest Catholicism from a strategy of cultural domination to a nationalistic paradigm (1-344). Jameson offers as a paradigmatic example Ernst Bloch's rereading of the fairy tale in which the fantasy and wish-fulfillment registers of the genre, with their dreams of magic and plenitude, unsettles the "hegemonic aristocratic form of the epic, with its somber ideology of heroism and baleful destiny" (Jameson 86). Jameson also sees a similar class investment in the development of folk music and peasant dance. These two forms, originally expressions of a humble farming class, were appropriated by the aristocracy who transformed both into the instruments of an intricate courtly dance (Jameson 86) used as historico-cultural signposts, for instance, in the movie adaptations of Jane Austen's novels. In this manner is how class values assume shape, narrative or otherwise; a class' production of or investing in particular forms of discourse (i.e poem, music, narrative) does not merely maintain the integrity of the class-it also disarms that which it relates with. A discourse is hegemonic because it protects its identity as well as undermines middle-class aspirations in the same way that a discourse of the working class affirms itself while discrediting upper class notions of nobility and honor.

Class discourses are structured along raw material which Jameson calls an 'ideologeme,' an indivisible ideological unit whose structural features may take the form of a philosophical belief or a narrative expression of a class fantasy about an opposing group, and sometimes the recourse to both, projecting the former into the apparatus of the latter (Jameson 87). As raw 
material, ideologemes are the available pre-existing structures suggestive of a class content which are absorbed and modified in newly-produced cultural forms.

Jameson discusses Gissing's novels at length to demonstrate how inherited narrative ideologemes from the Dickensian "angel of the hearth," sentimentality and melodrama, Victorian renunciation, to the alienated intellectual are reworked as raw materials in Gissing's experimental narrative apparatus, in its mediation on individual and collective destinies, in order to resolve symbolically the class antagonisms and anxieties of which Gissing is heir (Jameson 185-205). This expanse of narrative structures and strategies which the novelist adapts into his oeuvre reveals the actual complexity involved in the textual construction given the new social problems and anxieties which mark the social period of Gissing's novels. That the text is this process of substitution and displacement and not a matter of an originary creativity finds concrete illustration in the thorough ideological recuperation by which Gissing's narrative draws in lived experience in a social structure's network of class relations. This demonstration approximates the mode in which this study pursues its own restructuration of the Faulknerian ideologemes in Groyon's novel.

\section{The Ground and the Sky}

The pervasive symbols of the ground and the sky are binary oppositions deployed in Groyon's novel to represent truth and its impossible straightforward telling, respectively. This binary opposition, given its overdetermined representation, also limns the other elements in the story.

In the novel, the ground, which is one term in the binary opposition, is associated with derogatory qualities. To it are conjoined notions of "truth"/"essence," "the past," "family secrets," "filth," and "corruption." These meanings overlap in several instances in the novel.

In the beginning of the novel, George withdraws from the peering eyes and voluble tongues of Bacolod and holes himself up in Hacienda Dimas, which is by itself a symbolic gesture. George declares, in a dramatic preamble, the purpose of his journal: 
I will tell all, all of the things that people don't want me to tell, all the things that were hidden, buried, driven out of sight into the dark until everything grew over it and hid the signs that anything had ever been buried there to begin with (12).

Such a figuring of truth, and the past as hidden and buried likewise appears in George's journal as a comment on a dominant Negrense trait:

Out here, we see a spade we dig. We throw everything into the pit and we cover it up. That's all over now. I'm here, and no one is going to come after me. I'm the Savior of this family, sent to rescue it from all the lies it's built around itself to make sure everything is nice and polite (13).

These three references to "hiding" represent a meaning of 'ground' as a mass or receptacle of unearthed truth and skeletons in the closet that have yet to be disclosed. The big reveal at the end of the novel, of course, unearths a literal skeleton. The trope of hiding is likewise used to refer to Faustino's journal, which George describes as "emerg[ing]" from hiding."

Another connotation of ground is generated from its affinity with land. Land and its attendant connotations in Negros are given a less than affirmative take in the novel, but most especially so by Rafael who scorned the trappings of hacienda life and relates anything close to the ground with working-class sensibilities and habits. He, for instance, chose to move in to a high-rise condominium in Manila the first chance he got to leave Bacolod, since the set up allowed him to be as far away as possible from "the smog and filth of the earth" (111).

A similar use of the idiom of distantiation, which straddles the symbols of earth and sky, appears in the description of the plaza in Bacolod given by Rafael on his way to Dimas:

The plaza had long since become the congregation point for the underbelly of Bacolod society prostitutes, the jobless, and homeless. Rafael spotted 
several vagrants taking advantage of the gazebo's shelter and the relative comfort of the stone benches which, he noted, also lifted the sleepers away from the earth. His compulsion to distance himself from Bacolod and the land that was his birthright was, after all a natural human instinct. Whereas highrise condos took it to a ridiculous extreme, they observed the same principle - to be close to the earth was to be a lower form of life, unless the earth was mastered, controlled, forced to provide sustenance. And it all had to be done without getting one's hand dirty, or else it didn't count (116).

This aversion towards things associated with the earth finds its way in Rafael's picturesque memory of the workers in Hacienda Dimas. In his observation of the workers' routine during payroll time, it is their tough feet and nothing else that attract his attention. He describes:

They would invariably be broad, solid, like the roots of an ancient tree, creased, and cracked, chalky ridges limning the whorls and calluses, skin the texture of guava tree bark. They seemed not to belong to the body; just protruded from an old pair of gabardine slacks with twice-lengthened pant legs. The feet made respectful padding noises as they approached the desk, and the whisper of their rough skin as they brushed against each other when one foot is nestled on the other ankle under the chair was loud in the quiet room, even louder than the rustling of papers while the payroll records were brought up to date (110).

The condescension that reduces the workers' identity to the appearance of their feet, a synecdoche for the reification of their labor, extends to the manner in which walking in Bacolod is said to be a humiliating exercise for the affluent. Rafael recalls being shamed by a car full of girls who happened to see him walk the five minutes from the gate of his subdivision to his house because the family driver was unavailable (117-118). 
The symbol of ground likewise connotes 'dirt,' and 'truth' which not only suggest "what happened" but also 'indiscretions' and 'peccadilloes.' It is used in such a context in this substitution. An entry in George's journal narrates how George had eavesdropped on Marge's confession that her first son was actually Rodel's and not George's. Marge admitted to fooling George into thinking that that son was his. George made noises to indicate that he forgives her but later on says: "She told me Truth, and I wanted to throw the real Truth back at her" (58). Truth in this passage is couched in terms that make it seem as if it were dirt or muck being hurled at someone's face.

In contraposition to 'ground,' the symbol of 'sky' in the novel is invested with more desirable and privileged values. 'Sky' is conflated with ideas of distance, release, layering, and "telling." Among the characters in the novel, it is Rafael who stands for the wish-fulfillment registers of 'sky' in the novel. As can be gleaned in an earlier excerpt, Rafael disdains things close to the ground, and as consequence, lives in Manila, in high-rise condos, away from the messy affairs of his family in Manila.

Because he didn't want to "get his hands dirty," a running euphemism in the novel which suggests involvement, Rafael was unaffected when support for the EDSA revolution was in full swing in Bacolod. The narration attributes his forgetfulness to "his tendency to pass judgment from a distance, or a great height" (132).

In the last chapter of the novel, written curiously in italics and from the point of view of an omniscience different from the general narration in the novel, Rafael sits in his apartment, pondering the contents of both George's and Faustino's journal, which he's read over and over. As he's about to sleep, the narration turns to a contemplation of his figure:

Still the question arises. It's always the last thing he remembers before he drops off to sleep. His gentle snoring - an inherited trait, naturally - releases it as an invocation to the sky, which remains unmoved and doesn't answer (258). 
This last paragraph of the novel establishes a connection between the sky and the idea of release in transforming Rafael's question about his family's story into a prayer thrown at something incapable of responding.

Another passage in the same chapter makes a similar reference although the import of the symbol has now shifted somewhat in significance.

He's alone in his apartment, and he feels it especially in the way that the noise of the unseen traffic below wafts up to him, disembodied and ephemeral. High above him, the Pleiades trace their arcs with stately grace, as invisible to him, as vehicles on the streets below (257).

Aside from the suggestive description of traffic noise as disembodied and ephemeral, adjectives that seem too ambitious and too big to refer to something as banal as traffic and are clearly correlatives of the sky, the quoted lines take the focus of the narration to something as ridiculously high up as the Pleiades, a nebulous star cluster predicted to have dissolved some 250 million years or so. This particular and conspicuous articulation of the sky through the specter of the Pleiades as hazy and indeterminate is suggestive of the novel's dominant narrative gesture of fabulizing or "telling," which is only to be expected from a historiographic metafiction. In the novel, gossip, fabrication, rumors, and telling glut the narration and are construed to be one and the same provisional operation.

Apart from the instability of narration, "sky" underpins the articulation of other elements, suggesting, sometimes in an overstated fashion, the impossibility of arriving at fact or truth when its expression can never really be a transparent medium. Details of setting, character, and point of view are animated by this register of the symbol. An instance is the Jarabas mansion whose lopsided structure spills over to the mismatch between the intended function of its rooms and their actual use (40). This description renders the idea of layering as a contiguous expression of "telling," suggesting the impossibility of discerning which part of the house forms its architectural starting point. The last sentence in the quoted description likewise indicates 
a similar muddling of intentions. The manor in Dimas, which is bizarre and asymmetrically-built, is also described in the same terms.

The notion of telling as fabulizing or fabricating undergirds the narration of both George's and Marge's family history. In fact, the novel constantly refuses to verify things as factual despite its recurring prefatory statements 'fact is' or 'truth is" and qualifies most of the incidents surrounding the family's stories as gossip or speculation. In fact, all three Torrecarions resort to fabrication when convenient. Rafael, for instance, admits to adulterating truth with fiction in relaying his background to his girlfriend in Manila (15). Marge, who falls into bouts of airiness, blackmails Rafael emotionally by feigning helplessness and hysteria one day and commanding him with her iron will the next.

In writing his diary, George stipulates that the statements in Faustino's journal are speculations and embellishments, pressed to the service of mythmaking. Challenging the facticity of Faustino's memoir of his arrival in Negros, George notes:

This is the story as it begins in the book, as everyone, all of Negros, knows it: that Faustino Torrecarion stepped off the boat, the galleon that he doesn't name, that had taken months to travel here, bearing a fresh-faced land of 18 who traded labor for passage, who, through hard work and determination, carved out a space for himself in rapacious boomtown that was Negros, and established a powerhouse of a family in the process. Lies. All of it lies. Truth is, he was a boy of 18 when he arrived, but he could have been brought here on a prison boat for all we know, and there isn't much documentation about him until much much later, when at 34 he married a local girl. By then he had a vast tract of land to his name, how it came to his possession no one knows, and was producing sugarcane for the Empire. This is where truth begins, if you can call it that. At least there are records to corroborate the facts. Everything before that, every- 
one thinks they know to be true, but it isn't.

Much of it came from Faustino himself. Stories were told by people, on to the other, this is true, but the stories were all his own making. All of them. He claimed he had begun working at the docks and worked his way inland, until he got to the mountains. Little anecdotes dropped here and there for everyone's benefit, embellished with each retelling by admirers, enemies, envious gossip-mongers, until all of it took on the patina of Truth, by dint of having been repeated for so long (31-32).

Such a tangential and accidental production of "truth" brought about by an accumulation of inventions, retellings, and hearsay is the novel's central thematic concern, underscoring the impossibility of knowing the truth or telling it straight. Given this focus, it is understandable why the novel privileges gossip and a collective perspective which attributes the source of pseudo-testimonial statements about the Torrecarion and Jarabas families to "all of Bacolod" or "all of Negros." The repeated emphasis on fabulizing and telling, whose frequency in the novel inundates the whole story, can be read as an undermining of history's referential status and fiction's imaginary one. This binary opposition is deconstructed in the novel in its swapping of signifieds. By marginalizing "truth" and privileging fiction, summed up as narrating a story or relaying what happened or what one has overheard, the novel provisionalizes history. Thus after George dies the fact seems to do so, so to speak, and causes a commotion, a celebration in fact among the wagging tongues of Bacolod, not unlike the multiplication of languages in the Tower of Babel (249).

In its overdetermined use of the symbols of "sky" and "ground," the novel further invests the pair with meanings related to genealogy in keeping with its subject of a family saga. In its suggestion of truth as something singular and straight and of lies or fabrications as something multiple and warped, the narration strikes a parallelism between truth as genetic normality and "logical outcome" and telling as degeneration, insanity, and class miscegena- 
tion. In this permutation of the binaries, history, in its linearity, is conflated with the concept of bloodlines, which is illustrated mainly by George, who points an accusing finger at Faustino, so to speak, for bringing in what he perceives as the craziness in his family, his euphemism for the act of murder and other human grotesqueries. Thus Torrecarion, a "tower of carrion" aptly characterizes George's family as poachers on land, social status and anything that secures either.

In contrast to this attribution of character to atavistic tendencies, the trotting out of family members who stain and deviate from the pureness of Negrense pedigree are adopted like Ansing, illegitimate like the first son Rodel, stillborns or idiots like Jan, a son of a German hacendero family who settled in Bacolod, and women who marry below or above their class like Marge and her mother Aida are token characters representative of the idea of mutation.

In fact, in what could only be called an over-privileging of "telling," George and Rafael's last moments in the story casts doubt as to whether the latter is actually the son of the former. In their final minutes together in Dimas, George marvels at how Rafael could very well be him when he was young given their striking resemblance. This affirmation of their being related though is challenged when George notices for the first time that Rafael has asthma and is puzzled by it since both sides of the family are not predisposed to it. George wonders "where" his son got it, implying that the disorder couldn't have been passed on from either parent. The last lines of the novel seemingly make a ploy of the whole matter in describing Rafael's snoring as "an inherited trait, naturally."

\section{Class Discourse in The Sky over Dimas}

The second interpretive ground, the social, reconstructs the text as an articulation of a class discourse. This ideological reconstruction of Groyon's novel examines the author's appropriation of a number of narrative paradigms or ideologemes from Faulkner's Absalom, Absalom! and Go Down, Moses. At this point, the novel is restored to its status as a class discourse of the elite, 
formed in the text's dialogue with an oppositional working class discourse, which it disarms and undermines. The contradiction that the novel now seeks to resolve is dialogical, embodied by "the irreconcilable demands and positions of antagonistic classes" (Jameson 83).

The geography of fifteen of Faulkner's nineteen novels is set in the American South, which the author has particularized into the imaginary locale of Yoknapatawpha County. Into this mythical Mississippi, Faulkner introduces seven families, whose arrival signaled the end of the Chickasaw Indian's sole ownership of the land. Some of these families bought their plot of land for cultivation into plantations from its original Indian owners. The first pioneers in this area are Lucius Quintus Carothers McCaslin, the patriarch who established a white and mulatto line of descent in Go Down, Moses and Thomas Sutpen, a migrant from Virginia in Absalom, Absalom! whose entry in Jefferson is summarily made known to be motivated by a "grand design" to gain social power by siring a line of aristocratic heirs. Most of the white characters in these seven novels are members of country or pioneering families. The pioneers like Lucius McCaslin and Thomas Sutpen have sired elite families in the area while the Negroes are servants of the white elite families (Volpe 13-15).

The Sky over Dimas is Faulknerian not only in the sense that Groyon, writing about a province in the South, might have been drawn to the same plot structure but more significantly in its appropriation of two narrative paradigms as objective solutions to the contradiction of class conflict in Dimas' historical moment. The first ideologeme, which is a narrative pretext in Absalom, Absalom! involves the formal paradigm of the feudal patriarch legitimizing himself in the eyes of a racially-divided society backwards, that is, by producing sons as heirs and marrying them off to elite white families whose status in society is the point of the whole narrative design. Groyon also works into the novel the ideologeme of "the sins of the fathers are visited on the sons" and a number of related narrative codes and characters derived from Go Down, Moses. The resemblance between Dimas and these two Faulkner novels, though, go beyond the former's appropriation of these 
two discrete contents and will become apparent later in the summaries of the two novels.

\section{Absalom, Absalom!}

Thomas, one of the sons of a poor Virginia mountaineer, was ten years old when his family moved east and saw for the first time wealthy white men who owned both Negro slaves and property. Naïve in his belief that men were equals and that money or possessions did not necessarily make one superior, just lucky, Sutpen was stunned and humiliated when, upon delivering a message to a manor, a Negro servant told him to go around to the back. Since then, Sutpen made a vow that he will fight back by becoming one of these men who can command slaves, money and possessions. Sutpen ran away to Haiti to make his fortune and married a sugar planter's daughter. He discovered, after the birth of their son, that his wife was an octoroon: she was one-sixteenth Negro. He divorced her knowing that his plan to establish a dynasty could never materialize if his wife and children had a drop of black blood in them. Sutpen reappears in Jefferson, Mississippi, with no perceptible past and no possessions except for one hundred French-speaking Negroes and a French architect. He apparently had acquired a hundred square miles of arable land from Ikkemotube, the Chickasaw chief which he paid for with his last gold coin. The house which he commissioned the Negroes and the architect to build was finished in two years. Sutpen lived alone in this house for three years, borrowing cotton seed from General Compson to plants his first crop. He furnished the house and married Ellen Coldfield, one of the daughters of Goodhue Coldfield, the most respectable man in Jefferson. Two children, Henry and Judith are born to them. Henry Sutpen, twenty-six years after his father's arrival in Jefferson, entered the University of Mississippi and became a close friend of Charles Bon, not knowing that Charles is the son of Thomas Sutpen by his Haitian wife. The two spend Christmas at Sutpen's manor and Ellen projects a marriage between Charles and Judith. The next Christmas, the two return to Jefferson; Thomas tells his son that Judith and Charles cannot marry because the latter is his son. Henry, refusing to accept his father's reason, repudiates his birthright and leaves for 
New Orleans with Charles. He finds out that Charles is not without black blood. The Civil War breaks the next spring and both Henry and Charles join a regiment. Thomas Sutpen also went to war under Colonel Sartoris' command. Charles and Henry stay together during the war and return to Sutpen's manor near the war's end. Henry shoots Charles in order to prevent the latter's forbidden marriage to his sister. Thomas Sutpen returns from war and finds his design to found a dynasty ruined. Ellen is dead, his son is on the lam, and Judith is virtually a spinster. Intent on salvaging his grand design, Sutpen offers marriage to Rosa Coldfield, the much younger sister of Ellen and the proposal would have been accepted by Rosa had he not insulted her by giving the condition that he would marry her if she gives him a son. Sutpen sleeps with Milly, the fifteen-year old granddaughter of Wash Jones, his poor-white handyman. Milly's child is a girl and Sutpen dismisses both mother and child. Wash Jones kills Sutpen over his lack of compassion. Judith continues to live in the plantation manor with Clytie, her mulatto half-sister. Judith sends Clytie to New Orleans to bring back Charles' son, Etienne, by his octoroon mistress. White in appearance, Etienne is raised by Judith and Clytie to think of himself as Negro. He repudiates his white blood and marries a very black Negro woman, who bore him an idiot son, Jim Bond. Etienne catches yellow fever and so does Judith while taking care of him and both die. Several years after, Rosa Coldfield discovers that someone besides Clytie and Jim Bond is living in the by now dilapidated Sutpen manor. Summoning Quentin Compson, who accompanies her to the manor, she finds Henry in hiding, unwell and emaciated but cared for by Clytie. Three months later, Rosa brings an ambulance to take Henry to the hospital but Clytie, thinking that Henry is being taken to for the killing of Charles, sets fire to the house, killing both her and Henry. After the death of these two, Jim Bond is left as Sutpen's only descendant.

\section{Go Down, Moses}

Lucius Quintus Carothers McCaslin migrated to northern Mississippi, in the early nineteenth century, where he bought a vast tract of land from Ikkemotube. He also bought from this Indian chief a quadroon slave woman 
and her young child, Sam Fathers, the chief's illegitimate son. McCaslin sires three legitimate children-the twins Buck and Buddy, and a daughter. His two illegitimate children by his Negro slaves are Tomey, the daughter of Eunice and Tomey's Turl, his son by his own daughter Tomey. After Lucius McCaslin's death, Buck and Buddy moved out of the half-completed plantation house and into a cabin they had build themselves. Rejecting the practice of slavery, both tried to let the slaves on the plantation work out their purchase price in order to earn their freedom. The Negroes though refuse to leave once freed. Buck, in his 60s, marries Sophonsiba Beauchamp who bears him a son, Isaac. Orphaned when he was twelve, Isaac/Ike is partly raised by his cousin, Cass McCaslin, the grandson of Lucius McCaslin's daughter, who is older than him by sixteen years. Ike trains to be a better hunter and woodsman under Sam Fathers. He discovers, at sixteen, through his father's old ledgers, the miscegenation and incest his grandfather had committed, and thus came to believe that the South was cursed with the guilt of slavery and that his family was cursed by Lucius' acts. When he turns twenty-one, Ike declines the inheritance of the family's plantation although it is rightfully his, believing that the land is the common property of all men. The plantation goes to Isaac's cousin, Cass. Isaac marries but his wife exacts vengeance on him for renouncing his inheritance by refusing him her bed. Ike thus remains childless and spends the rest of his life in his wife's house, receiving a small allowance from Cass when his wife dies. Cass dies and the land goes to his son Zack. A friend and a rival of his Negro cousin Lucas Beauchamp, Zack “borrowed” Lucas' wife Molly for six months to care for his infant son, who was orphaned of his mother at his birth. Molly raises Zack's son Roth and his own son Henry together, as if they were brothers. When he turns seven, Roth comes to realize that Henry is black and since then rejects him as an equal. Each generation of Edmonds, Cass' and Zack's line, proves to be of less dignity than the one before it. Cass was a better man than Zack who is better than his son Roth. Seventy-three years after Isaac's birth, Roth has an affair with a light-colored Negro woman who bore him a son but whom he refuses to marry. Ike meets this woman and finds out that she is the grand- 
daughter of James Beauchamp, the son of Tomey's Turl. Thus the black and white McCaslin bloodlines are again fused.

Most of Faulkner's novels, and especially the two cited above, beneath their dominant formal surface of the individual man torn between the natural/ethical/moral and the social, are narrativized inflections and implications of the abuse of power. Into his versions of the family romance in these two novels between Ike and Sam and among Henry, Charles Bon, and Judith, Faulkner introduces the "intricacies of class, race, and gender relationships." Courage, honor, compassion and other virtues that Faulkner invokes in these novels are, in their deep logic, social and Other-regarding virtues, understandable only in the structures of power that he locates in his fictional and historical South (King 24).

These two novels of Faulkner thus may be seen to dramatize and question the dominant ideologies or master narratives of Southern history. In their figuration of the prominent characters of strong-willed, self-made, and demonic patriarchs, Go Down, Moses and Absalom, Absalom! are founding narratives, which relate the curious story of a family's origins as basis for the formation of society. Although both McCaslin and Sutpen occupy dominant positions in Jefferson, both are interlopers and truants of the Southern social code. Their entry into town with the intent of establishing a dynasty is predicated on miscegenation, incest, and a quick amoral dismissal of such transgressions (King 29). McCaslin sleeps with his mulatto daughter who commits suicide as a result. This elder McCaslin's cruelty reappears further down the bloodline when his great grandson, Roth Edmonds, refuses to acknowledge his ties with the black woman he slept with and his mulatto son that she bore him. Sutpen rejects his Haitian wife and first son Charles Bon because both had a trace of Negro blood in them, and grooms Henry to kill Charles. Henry is guilty of the same prejudice in first allowing Charles and his sister to marry, despite the knowledge that Charles is their brother, and then withdrawing his consent when he discovers that Charles is black, his fear of miscegenation overwhelming his fear of incest.

Both novels dramatize the failure of these patriarchs to recognize the curse they bring upon themselves and their families for exploiting nature 
(incest) and human beings whose social status as Negroes effectively efface their basic dignity as persons. Faulkner also grounds the subject of the Southern "curse" further in Go Down, Moses in the fifth story, The Bear, which occasions a discussion between Ike and Edmond regarding the former's surprising renunciation of his legacy when he discovers the violation committed by his grandfather. Ike supposes that the land on which they built their plantations was cursed even before Lucius McCaslin's arrival since Ikkemotubbe, the original owner of the land, sold it for money and could thus amount to nothing now. Ike, though, muses that this does not exactly absolve white men because it was God's plan to use the inhumanity of white men to work out this curse until it is brought to its end (King 31-32).

The summaries of these two novels and their subsequent readings make apparent Groyon's comprehensive assimilation of the narrative material in these two works in his own novel. Although Groyon freely integrates into his novel more than the two ideologemes in Faulkner mentioned earlier, The Sky over Dimas like Absalom, Absalom! resorts to a complex narrative perspectivism which divides the story between two or more characters to dramatize the nature of truth, only these two are invested with what could be called a class content.

In its original prominent form in Absalom, Absalom!, the paradigm of Sutpen's "grand design" is a particularization of the dominant Southern code, which had instituted the superiority of whites over blacks and has legimitized the practice of slavery. This code is criticized in the novel when in the end, Sutpen dies and without any descendants to carry his name except for his idiot great-grandson. Groyon assimilates this material by adapting an incident in the history of Negros as a back-story for the character of Faustino Torrecarion, which appears in the novel as one of George's speculations about Faustino. Introduced as a reincarnation of Sutpen, Faustino, arrives in eighteenth-century Bacolod with a murky past and proceeds to recreate himself as a formidable sugar hacendero by strategically marrying a farmer's daughter, younger than him by fifty years, whose family is evicted from the plot they used to till. Unlike Sutpen who bought property from the Indian chief, Faustino's ownership of his first tract of land is occasioned by his prof- 
iteering as a middleman merchant, buying goods in kind from the Maghat, a historical pre-colonial tribal community who was known to have lived in the Karul-an hills in Negros, and selling them for big profits. Fearing that his profit over the small trade he has established with the Maghat might end once the latter are re-settled in the Christianized areas downtown, Faustino misrepresents the nature of the Maghat tribe to then Governor General Saravia; he tells Saravia that the Maghat are violent and are responsible for raping two local women. Saravia believes him and orders his men to attack the tribe. Helpless with their crude spears and knives, the leader of the tribe is shot. Seeing that their leader is killed, the members of the tribe set fire to the huts where they were hiding. The fire wipes out the entire tribe despite the Spanish soldiers attempts at rescue. Within a year, Faustino is awarded the land that the Maghat were supposed to occupy, had their assimilation to the Catholic religion been successful, by the Spanish court. George invents this historical event as a fitting back-story to Faustino's entry into island life while reading and revising the latter's journal, almost similar in action but not in import to Ike McCaslin's perusal of his father's ledgers and through them, discovering his grandfather Lucius McCaslin's terrible deeds, which is the second ideologeme assimilated by Groyon in his novel.

These narrative materials in Absalom, Absalom! and Go Down, Moses, articulate a class ideologeme that demonstrates the futility of white man's self-aggrandizing act in its basic prohibition of any union with the blacks that might corrupt his pure aristocratic line. Thus the way this ideologeme is worked out to its narrative conclusion in Faulkner's novels challenges the dominant ideology of the South's white men whose perverse drive for self-creation and a preservation of power through genealogy, which safeguards their purity of line from black blood, is nevertheless shown to be empty, deluded and fruitless. Groyon transmutes this material, originally a discourse that defends the laboring class articulated in the historical moment of racism and slavery in the American South, into the very different one of the conflicting groups of the landed elite and the working class in Bacolod. Although both the narrative contexts in Faulkner and Groyon demonstrate how power relations determine and distort social relations, the loosing of 
the content from its former context and its insertion into a narrative act quite different from the original's historical moment, has effected a modification in the ideologeme's function in Dimas. Whereas this ideologeme in Faulkner undermines the inhumanity of the racial code in the American South, this material in Dimas is neutralized by its provisionalizing impulse and co-opted by the rhetoric of the landed elite's denial of their responsibility in perpetuating an unjust socio-economic structure in the sugar industry. Dimas' historical context opens up to the longstanding agrarian conflict between the sugar hacenderos and the working class. The former, who practically know nothing about farming or planting sugar, own most of the cane lands while the latter, thrice the landed elite's numbers, remain tenants, their income dependent on the monocrop industry of sugar, and the feudal practices of the hacenderos. In this rife situation of conflict, the workers' cause took the form of appeals for land reform and a diversification out of sugar to broaden their source of income while the hacenderos feigned helplessness and a similar feeling of entrapment, all the time blaming the situation of their workers on the "system" instead.

In its provisionalizing of Torrecarion history, the novel transforms this adapted Faulknerian ideologeme into a pure conjecture by George who weaves it into his biased and guilt-impelled speculation of his family's past. Thus this synthesis of Faulknerian instances of the patriarch's "grand design" in Absalom and his monstrous violations against blacks in Go Down, Moses is neutralized as a lore, a particular moment in George's defense of his morality by imputing, repeatedly, to the first Torrecarion and his entire family line the sin he committed when he kills Rodel, the working-class father of Marge's first son. Rafael, who brings with him Faustino's and George's journals to Manila, refuses to accept any of George's confessions as true. Unlike the figure of Ike McCaslin, whose gesture of confronting his grandfather's "original sin" and renouncing his legacy furnishes the content of the second ideologeme, Rafael renounces his legacy, but only artificially/outwardly, by escaping to Manila, unchanged and unrepentant, merely relieved that all that drama and gossip about his family seem to be over. Thus the narrative sidesteps a confrontation of the sugar elite's culpability in the novel's conclusion 
and this swerving is that which, though muted, effectively undermines the subjectivity of the working class whose destitute state in the sugar economy is mimicked and co-opted by the landed elite who feign a similar feeling of entrapment and misery. Rafael's persistent denial of George's crime after seeing Rodel's remains and reading George's journal, in its inner class logic, is a denial of the concrete, historical humanity of the working class, people Rafael reduces to the work they do that cannot but demand daily and exhausting contact with the land, the same land which his entire life has been given to renouncing.

In The Sky over Dimas, the main characters are clearly allegorical equivalents of the families of sugar hacenderos in Negros whose protracted ownership and monopoly of the land has assured them of social and cultural power as well. This feudal system of the sugar industry in Negros, which is marked by the abject poverty of its sugar workers, inequitable labor relations, military and NPA violence, and the conspicuous consumption of its landed elite (Aguilar 2, Billig 1-250, Berlow 63-199) constitute socio-historical subtext that the novel is a response to. Although it is clear in any history of Negros that such feudal practices are perpetuated by the clique of hacenderos in order to maintain their dominant position in the status quo where only five percent of the population control the circulation of wealth in Negros, Dimas represses this fact in its depiction of George as a reluctant, sugar-weary hacendero and instead explains this iniquitous and volatile situation by stating that "sugar is evil," a reification which naturalizes its operations, its essence as itself a curse, bound to cause misery wherever it is planted. This view of sugar is replicated in the novel's statement about blood, which once again becomes George's and Rafael's convenient scapegoat: the former blaming his bloodline for his amoral acts, and the latter, demonstrating that there is no escaping one's genetic inheritance. These naturalized modes in the novel are not mere metaphorical instances or stylizations but are symptoms of the text's provisionalizing of history. These narrative gestures humanize its elite characters by absolving them of guilt, making them sympathetic figures, and construing their failures as inevitable: natural outcomes of blood and object logic. 


\section{Works Cited}

Bakhtin, Mikhail. Speech Genres and Other Late Essays, edited by Caryl Emerson and Michael Holquist. U of Texas P, 1986.

Berlow, Alan. Dead Season: A Story of Murder and Revenge on the Philippine Island of Negros. Pantheon Books, 1996.

Billig, Michael. Barons, Brokers and Buyers: The Institutions and Cultures of Philippine Sugar. Ateneo de Manila UP, 2003.

Faulkner, William. Absalom, Absalom! Modern Library College Edition.

Vintage International, 1964.

- - -. Go Down, Moses. Modern Library Edition. Random House, Inc., 1995.

Groyon, Vicente. The Sky over Dimas. De La Salle UP, 2002.

Ileto, Reynaldo. Pasyon and Revolution: Popular Movements in the Philippines, 18401910. Ateneo de Manila UP, 1979.

- - -. The Political Unconscious: Narrative as a Socially Symbolic Act.

Cornell UP, 1981.

King, Richard. "Faulkner, Ideology, and the Narrative" in Faulkner and Ideology:

Faulkner and Yoknapatawpha, edited byAnn Abadie and Donald Kartiganer.UP of Mississippi, 1995.

Roberts, Adam. Fredric Jameson: Routledge Critical Thinkers. Routledge, 2000.

Volpe, Edmund. A Reader's Guide to William Faulkner. Lowe and Brydon Ltd., 1964. 